\title{
RESISTANCE OF VEGETATIVE CELLS OF CLOSTRIDIUM WELCHII TO LOW $p \mathrm{H}$
}

\author{
R. G. A. Sutton And Betty C. Hobis \\ School of Public Health and Tropical Medicine, University of Sydney, N.S.W., \\ and Food Hygiene Laboratory, Colindale Avenue, London
}

CLOSTRIDIUM WELCHII is now firmly established as a major cause of food poisoning, at least in England, the USA and Japan. It is generally agreed that the minimum infecting dose is high; Dische and Elek (1957) concluded that a dose of c. $5 \times 10^{8}$ viable organisms was necessary to produce symptoms.

The present paper deals with attempts to determine quantitatively the effect of low $p \mathrm{H}$ $(1 \cdot 5-3 \cdot 6)$ on the survival of $\mathrm{Cl}$. welchii, and to relate the results to the possible survival during passage through the stomach of the large number of organisms needed to initiate infection.

\section{MATERIALS AND METHODS}

Technique. $10-\mathrm{ml}$ volumes for 5- and 24-hr cultures of $\mathrm{Cl}$. welchii in cooked-meat medium (CMM) were centrifuged, and the organisms were washed three times with quarter-strength Ringer's solution and resuspended in 10-ml volumes of 1 per cent. peptone water. Millilitre samples of these suspensions were inoculated into $100 \mathrm{ml}$ of peptone water of the required $p \mathrm{H}(1 \cdot 5-3 \cdot 6)$ or into human gastric juice in 150-ml screw-capped containers, and the diluted material was mixed by inversion. Millilitre samples were immediately pipetted into $6 \times \frac{5}{8}$ in. $(15 \times 1.5 \mathrm{~cm})$ test-tubes, which were placed in a $37^{\circ} \mathrm{C}$ waterbath for short-term tests or in anaerobic jars if the test was to last for more than $2 \mathrm{hr}$. Results from tests under aerobic conditions did not differ from those obtained under anaerobic conditions.

The reaction was timed from the moment the organisms were suspended in the low- $p \mathrm{H}$ material; duplicate $1-\mathrm{ml}$ samples were immediately placed in buffer to provide a zero reading. After a range of time-intervals, duplicate samples were removed from the waterbath or incubator and neutralised by the addition of $9 \mathrm{ml}$ of buffered quarter-strength Reinforced Clostridial Medium (RCM). Serial dilutions were made in quarter-strength RCM, and the number of survivors was counted on RCA by the surface plate technique. A drop from the 1 in 10 dilution was examined microscopically; the results were disregarded if clumping was prevalent. Fortunately there was little clumping with the strains used.

Organisms. The following strains were used: Clostridium welchii F 2063 and F 9191, both non-haemolytic and heat-resistant; F 8352 and NCTC8246, both $\beta$-haemolytic and heat-sensitive. All were isolated at the Food Hygiene Laboratory from samples connected with food-poisoning incidents.

\section{RESULTS}

\section{Tests in peptone water}

Survivor curves were drawn for vegetative cells of $\mathrm{Cl}$. welchii derived from 5- and 24-hr CMM cultures of all four strains of $\mathrm{Cl}$. welchii suspended in peptone water at each $\mathrm{pH}$ level from 1.5 to 3.6; the figure shows the curve obtained with strain F 8246. As the death rate was not always linear, decimal reduction times (D values) were not calculated. From the survivor curves the times taken to reduce the initial counts to 0.01 per cent. (i.e., an inactivation factor of 104) were calculated (table I). Rubbo, Gardner and Webb (1967) used a similar inactivation factor when they compared the death rates of bacterial spores in various concentrations of glutaraldehyde.

Received 17 Dec. 1970; accepted 12 Mar. 1971.

J. MED. MICROsIOL.—VOL. 4 (1971) 
At lower $p \mathrm{H}$ values $(1.5$ and $2 \cdot 0)$, when death was rapid, the death rate was primarily linear, but as the $p \mathrm{H}$ increased the survivor curves became sigmoid, with an initial lag period in which little change occurred in the number of survivors. Smith (1923) computed survivor

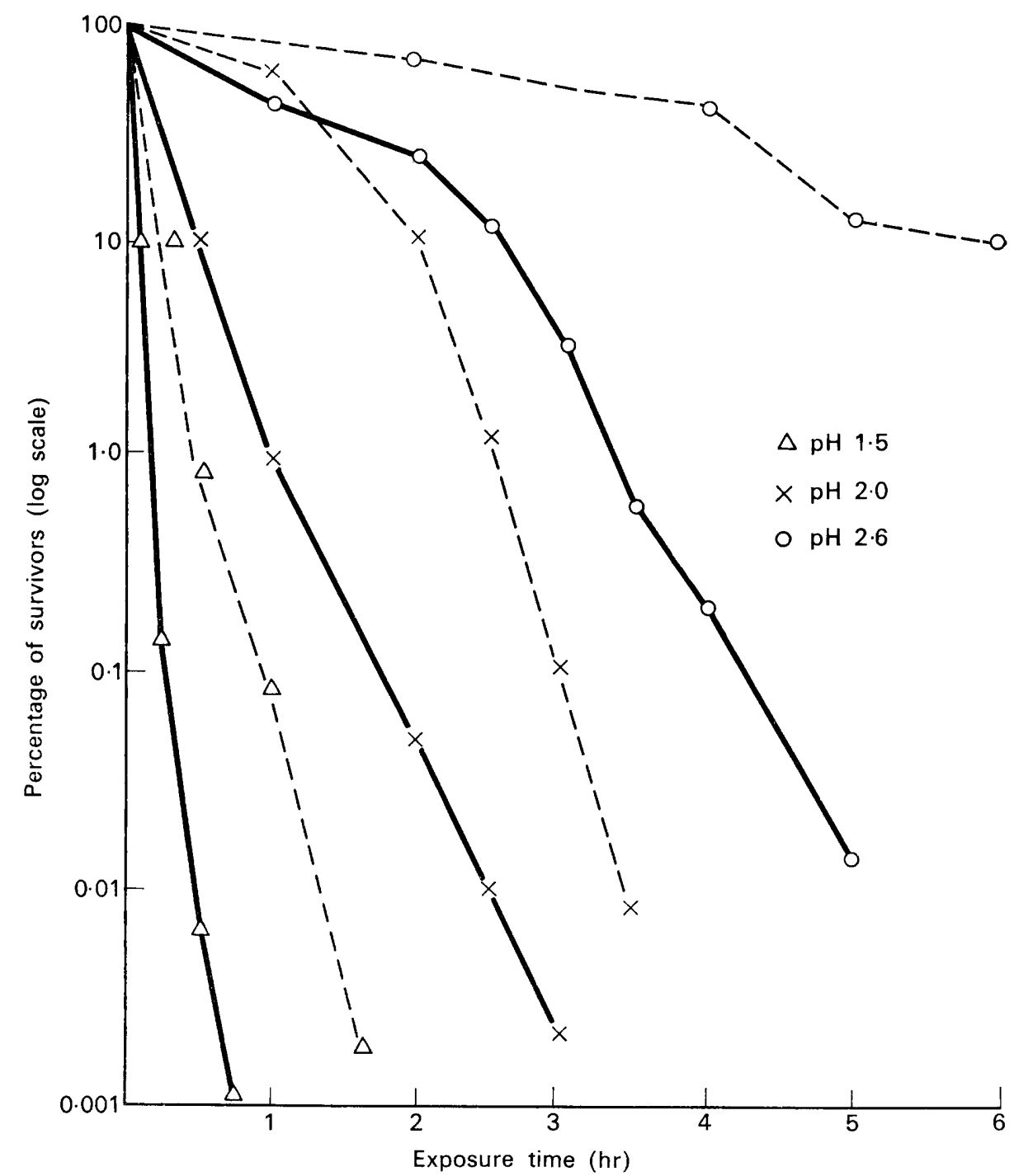

FIGURE.-Effect of low $p \mathrm{H}$ on the survival of vegetative cells of Clostridium welchii $\mathrm{F} 8246$ grown in $\mathrm{CMM}$ for $5 \mathrm{hr}(-)$ and $24 \mathrm{hr}(---)$ at $37^{\circ} \mathrm{C}$.

curves for the disinfectant action of a range of phenol concentrations and obtained similar results. He felt that the sigmoid curve was probably more representative of the true deathrate, because when the death-rate was high the initial lag period, though not eliminated, was so short that it was not detectable by normal counting methods.

For any given strain of $\mathrm{Cl}$. welchii the death rate increased with decreasing $p \mathrm{H}$. Above $p \mathrm{H} 3.6$ the death rate was small, and at $p \mathrm{H} 4.0$ and 4.5 little lethal action occurred within $24 \mathrm{hr}$. 
The $\beta$-haemolytic strains (F 8246, F 8352) survived for longer periods than the nonhaemolytic, heat-resistant strains (F 2063, F 9191).

The death rate was dependent on the age of the culture. The 5-hr cultures were more susceptible to low $p \mathrm{H}$ than the 24-hr cultures of the same strain. Although the incubation period was controlled at 5 and $24 \mathrm{hr}$, it was not possible to assume that all cultures were in exactly the same place of the growth cycle. Therefore, to obtain reproducible results with different cultures of the same strain, it was necessary to test at all $p \mathrm{H}$ levels with a single suspension of each culture.

TABLE I

Effect of low pH on the survival of vegetative cells of Clostridium welchii suspended in peptone water

\begin{tabular}{|c|c|c|c|}
\hline \multirow{2}{*}{$\begin{array}{c}\text { Strain } \\
\text { (and year) }\end{array}$} & \multirow{2}{*}{$\begin{array}{c}p \mathrm{H} \text { of suspending } \\
\text { medium }\end{array}$} & \multicolumn{2}{|c|}{$\begin{array}{l}\text { Time (min.) at } 37^{\circ} \mathrm{C} \text { for reduction of } \\
\text { viable count to } 0.01 \text { per cent. in a }\end{array}$} \\
\hline & & 5-hr culture & 24-hr culture \\
\hline F2063 (1967) & $\begin{array}{l}1 \cdot 5 \\
2.0 \\
2 \cdot 5 \\
3.0\end{array}$ & $\begin{array}{c}6 \\
25 \cdot 5 \\
68 \\
100\end{array}$ & $\begin{array}{r}35 \\
105 \\
181 \\
262\end{array}$ \\
\hline F9191 (1966) & $\begin{array}{l}1.5 \\
2 \cdot 0 \\
2 \cdot 4 \\
3 \cdot 1 \\
3.6\end{array}$ & $\begin{array}{r}11 \\
15 \\
22 \\
60 \\
185\end{array}$ & $\begin{array}{r}29 \\
56 \\
109 \\
210 \\
360\end{array}$ \\
\hline F8352 (1966) & $\begin{array}{l}1 \cdot 5 \\
2 \cdot 0 \\
2 \cdot 5\end{array}$ & $\begin{array}{l}280 \\
450 \\
950\end{array}$ & $\begin{array}{r}405 \\
750 \\
>1000\end{array}$ \\
\hline NCTC 8246 & $\begin{array}{l}1 \cdot 5 \\
2 \cdot 0 \\
2 \cdot 6\end{array}$ & $\begin{array}{r}30 \\
150 \\
300\end{array}$ & $\begin{array}{r}84 \\
205 \\
560\end{array}$ \\
\hline
\end{tabular}

Tests in gastric juice

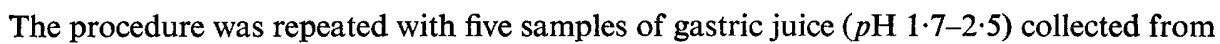
healthy students, and with one sample $(p \mathrm{H} \mathrm{7.0)}$ from a patient with achlorhydria. Because of their small volume, each sample could be tested with only one strain of $\mathrm{Cl}$. welchii. Table II gives the results, together with those for suspensions of the same strains, in peptone water at the same $p \mathrm{H}$. Vegetative cells of $\mathrm{Cl}$. welchii were evidently more susceptible to gastric juice than to peptone water at the same $p \mathrm{H}$, and the 24-hr cultures were more resistant to the bactericidal effects of low $p \mathrm{H}$ than the 5-hr cultures.

\section{Discussion}

Results from this work indicate that the acid resistance of an organism, and therefore its ability to survive passage through the intestine, is dependent on the age of the culture; young, actively growing cultures are more susceptible to low $p \mathrm{H}$ than cultures in the stationary phase of the growth cycle. We suggest that this may have an important effect on the results of feeding experiments. Hauschild and Thatcher (1967) produced diarrhoea in volunteers fed 
with (4-6) $\times 10^{9}$ vegetative cells from an 18-hr CMM culture, but Hauschild, Hilsheimer and Thatcher (1967) were unable to produce symptoms in patients fed with a similar dose of organisms grown for only $1-2 \mathrm{hr}$ in medium CP-2V. The latter authors found that the young cells were more susceptible to low $\mathrm{pH}$ and synthetic gastric juice than the older cells from the CMM culture. Dische and Elek (1957) stated that the variation in susceptibility of volunteers to Cl. welchii cultures depended on the survival of the bacteria in the stomach; this may be extended by saying that the survival within the stomach, and therefore the ability to cause food poisoning, is dependent on the physiological state of the host organism. This should be remembered when carrying out feeding experiments, either with human volunteers or experimental animals.

TABLE II

Survival of $\mathrm{Cl}$. welchii in samples of gastric juice and of peptone water at the same $\mathrm{pH}$

\begin{tabular}{|c|c|c|c|c|c|}
\hline \multirow{3}{*}{ Strain } & \multirow{3}{*}{$p \mathrm{H}$} & \multicolumn{4}{|c|}{$\begin{array}{c}\text { Time (min.) at } 37^{\circ} \mathrm{C} \text { for reduction of viable count to } 0.01 \text { per cent. } \\
\text { in suspensions in }\end{array}$} \\
\hline & & \multicolumn{2}{|c|}{ gastric juice of a } & \multicolumn{2}{|c|}{ peptone water of a } \\
\hline & & 5 -hr culture & 24-hr culture & 5-hr culture & 24-hr culture \\
\hline F8352 & $\begin{array}{l}1 \cdot 7 \\
2 \cdot 2 \\
2 \cdot 5\end{array}$ & $\begin{array}{r}45 \\
90 \\
120\end{array}$ & $\begin{array}{r}90 \\
200 \\
\ldots\end{array}$ & $\begin{array}{l}250 \\
240 \\
625\end{array}$ & $\begin{array}{r}480 \\
804 \\
\ldots\end{array}$ \\
\hline F2063 & $2 \cdot 5$ & $6 \cdot 5$ & 22 & 65 & 170 \\
\hline F8246 & $\begin{array}{l}2 \cdot 3 \\
7 \cdot 0\end{array}$ & $\begin{array}{r}23 \\
>1440\end{array}$ & $>14 \dddot{40}$ & $\begin{array}{r}180 \\
>1440\end{array}$ & $>1400$ \\
\hline
\end{tabular}

Duncan and Strong (1971) and Strong, Duncan and Perna (1971), in their work on the effect of $\mathrm{Cl}$. welchii on the rabbit ileum, used monkeys and human volunteers for feeding experiments. They observed that the effect on persons fed with viable cultures was increased if the cultures were taken with large amounts of food which, they suggest, buffered the acidity of the stomach.

\section{SUMMARY}

The resistance of vegetative cells of $\mathrm{Cl}$. welchii to low $\mathrm{pH}$ was tested in gastric juice and in peptone water of $p H \mathbf{1} \cdot 5-3 \cdot 6$. The results showed that, for any given strain the death rate increased with decreasing $p \mathrm{H}$; the death rate was dependent on the age of the culture-for cells grown in cooked-meat medium a 5 -hr culture was more susceptible to low $p \mathrm{H}$ than a 24-hr culture of the same strain; the cells were more susceptible to gastric juice than to peptone water of the same $p \mathrm{H}$.

\section{REFERENCES}

Dische, F. E., AND EleK, S. D. 1957. Experimental food poisoning by Clostridium welchii. Lancet, $2,71$.

Duncan, C. L., AND Strong, Dorothy H. 1971. Clostridium perfringens type A food poisoning. I. Response of the rabbit ileum as an indication of the enteropathogenicity of strains of Clostridium perfringens in monkeys. Infection Immun., 3, 167.

Hauschild, A. H. W., Hilsheimer, R., and Thatcher, F. S. 1967. Acid resistance and infectivity of food-poisoning Clostridium perfringens. Canad. J. Microbiol., 13, 1041. 
HAUSChILd, A. H. W., AND ThATChER, F. S. 1967. Experimental food poisoning with heat susceptible Clostridium perfringens type A. J. Fd Sci., 32, 467.

Rubbo, S. D., Gardner, JoAN F., AND WebB, R. L. 1967. Biocidal activities of glutaraldehyde and related compounds. J. Appl. Bact., 30, 78.

SMITH, J. H. 1923. The killing of Botrytis cinerea by heat, with a note on the determination of temperature coefficients. Ann. Appl. Biol., 10, 335.

Strong, Dorothy H., Duncan, C. L., and Perna, G. 1971. Clostridium perfringens type A food poisoning. II. Response of the rabbit ileum as an indication of enteropathogenicity of strains of Clostridium perfringens in human beings. Infection Immun., 3, 171. 